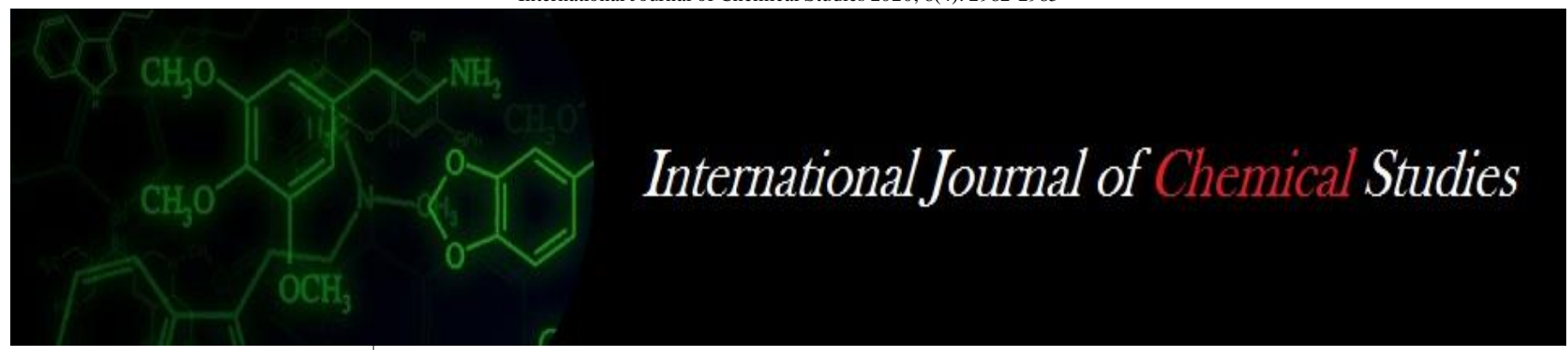

P-ISSN: 2349-8528

E-ISSN: 2321-4902

www.chemijournal.com

IJCS 2020; 8(4): 2982-2985

(C) 2020 IJCS

Received: 12-05-2020

Accepted: 14-06-2020

RS Lad

Ph.D., student Department of

Plant Pathology, Dr. P.D.K.V.,

Akola, Maharashtra, India

RM Gade

Associate Dean, College of

Agriculture, Gadchiroli,

Maharashtra, India

RJ Chaudhari

M.Sc. student Department of

Plant Pathology, Dr. P.D.K.V.,

Akola, Maharashtra, India

SP Wagh

M.Sc. student Department of

Plant Pathology, Dr. P.D.K.V.,

Akola, Maharashtra, India
Corresponding Author:

RS Lad

Ph.D., student Department of

Plant Pathology, Dr. P.D.K.V.,

Akola, Maharashtra, India

\section{Status of Phytophthora diseases in Nagpur mandarin orchards of Vidarbha region}

\author{
RS Lad, RM Gade, RJ Chaudhari and SP Wagh
}

DOI: https://doi.org/10.22271/chemi.2020.v8.i4aj.10102

\begin{abstract}
In central India the major cause of citrus decline is supposed to be because of Phytophthora causing diseases in citrus. The pathogen attack citrus plants right from nursery causing damping off of seedlings, decay of fibrous roots, crown rot, collar rot, foot rot and gummosis in mature orchards. Nagpur mandarins face short life span and low productivity because of these three species of Phytophthora viz. $P$. parasitica, $P$. citrophthora and $P$. palmivora. An intensive rapid roving survey of selected mandarin orchards was conducted during the year 2016 and 2017 to access incidence and intensity of Phytophthora diseases (root rot and gummosis). Total 83 orchards were surveyed during peak period of diseases (August to November) by using modified disease rating scale (0-9). According to rapid roving survey of root rot in selected orchards, pooled data indicate similar disease progress with root rot incidence in the range of 10.42 to $62.50 \%$ and intensity from 1.62 up to $23.48 \%$. In case of gummosis pooled data indicate similar trend of disease development with gummosis incidence in the range of 14.58 to $64.58 \%$ and intensity in between 2.08 to $19.91 \%$.
\end{abstract}

Keywords: Phytophthora, survey, mandarin, root rot, gummosis

\section{Introduction}

Nagpur mandarin (Citrus reticulata) is the most common among citrus fruits in India and is occupying a premier position among Indian mandarins. A large number of fungal diseases affect the crop (Meena and Shah 2005) ${ }^{[7]}$. Citrus plants are prone to attack of more than 150 diseases and disorders caused by fungal, viral and few bacterial pathogens right from nursery level to bearing stage resulting in incalculable losses (Lakshmi et al., 2014) ${ }^{[6]}$. In central India the major cause of citrus decline is supposed to be because of Phytophthora causing diseases in citrus. Phytophthora disease has been identified as one of the major causes of decline in citrus. It causes the most serious and economically important soil borne diseases to citrus crops. Three species of Phytophthora viz. P. parasitica, P. citrophthora and $P$. palmivora found associated to cause damping off, collar rot and root rot in citrus (Naqvi, 1988; Gade, 2012) ${ }^{[8,3]}$. The pathogen attack citrus plants right from nursery causing damping off of seedlings, decay of fibrous roots, crown rot, collar rot, foot rot and gummosis in mature orchards. Nagpur mandarins face short life span and low productivity because of these three species of Phytophthora (Das et al., 2011) ${ }^{[1]}$. The pathogen caused severe losses in Nagpur mandarin from nursery to orchard. The $24 \%$ mortality occur in nursery beds and $5-15 \%$ in transplanted seedlings/ grafts due to this pathogen (Naqvi, 2006) ${ }^{[11]}$. Phytophthora spp. cause the most serious and economically important soil borne diseases of citrus.

In Madhya Pradesh adjoining to Vidarbha region of Maharashtra, 20-50\% Nagpur mandarin plants were found to be affected resulting in severe decline due to $P$. parasitica, $P$. citrophthora along with P. palmivora. In Nagpur district 10-60\%, in Amravati 20-100\%, Akola 10-70\%, Yavatmal 20-100\%, Aurangabad 20-100\%, while, in Jalna $10-30 \%$ plants of sweet orange cv. Mosambi, Nagpur mandarin and acid lime were infected with Phytophthora spp. (Naqvi, 1993 and Naqvi, 1999) ${ }^{[9,10]}$. In recent time, gummosis incidence was recorded in between $14.00 \%$ to $50.50 \%$ whereas, gummosis intensity was in the range of $8.50 \%$ to $28.00 \%$. Similarly, root rot incidence was observed in the range of $18.00 \%$ to $40.00 \%$ while, intensity was recorded from $6.70 \%$ to $24.55 \%$ (Wagh et al., 2018) ${ }^{[13]}$.

An intensive rapid roving survey of orchards in contributes to assess the present status, distribution of plant pathogens prevalent in particular areas. Such surveys are helpful to 
characterize local isolates of pathogen. Epidemics of Phytophthora on heavy black cotton soils play an important role in citrus rootstock failure. Survey have been undertaken to see the association of Phytophthora spp. \& diseases caused by this pathogen in Vidarbha region where nearly $80 \mathrm{~L}$ grafts are being raised for sale every year (Gade, 2012) ${ }^{[3]}$. Phytophthora diseases affecting above-ground plant parts like leaves, stems or fruit are easily detected and diagnosed, root diseases below-ground may less visible and may detected after many years of infection (Tsao, 1990) ${ }^{[12]}$. Such surveys collect data at a single point in time; it is difficult to measure changes in the plant population unless two or more surveys are done at different points in time. Such repetition is often expensive and time-consuming, making frequent periodic surveys impractical.

\section{Materials and methods}

Amravati district is one of the major mandarin growing area in Vidarbha region. A rapid roving field survey was conducted to assess the incidence and intensity of gummosis and root rot diseases in Nagpur mandarin orchards of Amravati district of Maharashtra. Total 83 Nagpur mandarin orchards were surveyed during peak period of diseases (July to November) in the year 2016 and 2017 by using modified disease rating scale (0-9).To calculate disease severity or intensity of root rot and gummosis of citrus numerical rating scale was developed by modifying the scale of Gade et al. (2006) ${ }^{[4]}$ and Gade and Koche (2012) ${ }^{[2]}$. The similar scale was also used by Wagh et al. (2018) ${ }^{[13]}$ in their survey.

Disease rating scale for root rot: The intensity of root rot of citrus was recorded on the basis yellowing of leaves and drying of branches. The modified disease rating scale was used for recording observations by modifying scale of Gade et al. (2006) ${ }^{[4]}$. The 0-9 scale was used for root rot measurement as follows, 0- no yellowing, 1- yellowing of leaves and leaf fall (1-10\%), 3- yellowing of leaves and leaf fall (11-25\%), 5yellowing of leaves and leaf fall (26-50\%), 7- above 50\% yellowing of leaves and leaf fall and 9- drying of branches.

Disease rating scale for gummosis: The trees showing oozing of gum at bud joint and one meter above the ground level on the trunk were observed for calculating disease intensity of citrus gummosis. Observations on gumming were recorded on the basis of gradation as follows, 0 - healthy, 1oozing and lesion developed up to $1 \mathrm{~cm}^{2}$ area, 3- oozing lesion developed above $1 \mathrm{~cm}^{2}$ up to $2.5 \mathrm{~cm}^{2}$ area, 5- oozing lesion developed above $2.5 \mathrm{~cm}^{2}$ up to $5 \mathrm{~cm}^{2}$ area, 7- oozing lesion developed above $5 \mathrm{~cm}^{2}$ and 9- splitting of bark.

The disease intensity of both diseases was recorded by selecting twenty four plants from each plot. Per cent disease intensity (PDI) and percent disease incidence of the diseases were calculated by the formula used by Jagtap et al. (2012) ${ }^{[5]}$.

\section{Results and discussion}

An intensive rapid roving survey of selected mandarin orchards was conducted during the year 2016 and 2017 to access incidence and intensity of Phytophthora diseases (root rot and gummosis). Total 83 orchards were surveyed during peak period of diseases (August to November) by using modified disease rating scale (0-9). Survey indicated the presence of Phytophthora diseases in all selected mandarin orchards of Amravati district.

Table 1: Survey for incidence and intensity of root rot and gummosis in Nagpur mandarin orchards of Amravati (Pooled)

\begin{tabular}{|c|c|c|c|c|c|c|}
\hline \multirow{2}{*}{ S. No. } & \multirow{2}{*}{ Location } & \multirow{2}{*}{ GPS (Latitude / Longitude) } & \multicolumn{2}{|c|}{ Root rot } & \multicolumn{2}{|c|}{ Gummosis } \\
\hline & & & Incidence (\%) & Intensity (\%) & Incidence (\%) & Intensity (\%) \\
\hline 1 & Jarud & $21.463509 / 78.215042$ & 62.50 & 23.48 & 60.42 & 19.91 \\
\hline 2 & Bahada & $21.480949 / 78.204926$ & 35.42 & 9.72 & 25.00 & 8.79 \\
\hline 3 & Gavhan kund & $21.511707 / 78.198654$ & 41.67 & 14.81 & 35.42 & 14.11 \\
\hline 4 & Warud mahapur & $21.485443 / 78.251587$ & 39.58 & 13.42 & 33.33 & 11.34 \\
\hline 5 & Warud & $21.496702 / 78.266396$ & 31.25 & 10.88 & 42.17 & 7.40 \\
\hline 6 & Tivsa ghat & $21.505159 / 78.270630$ & 16.67 & 2.77 & 20.83 & 3.24 \\
\hline 7 & Pimpalshevada & $21.532314 / 78.252853$ & 58.33 & 16.66 & 54.17 & 14.12 \\
\hline 8 & Zatamziri A & $21.537823 / 78.241547$ & 18.75 & 2.54 & 20.83 & 2.54 \\
\hline 9 & Zatamziri B & $21.535418 / 78.272522$ & 35.42 & 6.71 & 33.33 & 5.32 \\
\hline 10 & Rawala & $21.553238 / 78.275665$ & 37.50 & 9.26 & 43.75 & 6.71 \\
\hline 11 & Shendurjana ghat & $21.518757 / 78.296188$ & 33.33 & 7.40 & 25.00 & 6.94 \\
\hline 12 & Pusala & $21.501884 / 78.358276$ & 52.08 & 14.35 & 39.58 & 12.96 \\
\hline 13 & Sawangi & $21.479252 / 78.378899$ & 39.58 & 14.58 & 33.33 & 10.18 \\
\hline 14 & Udapur & $21.437040 / 78.339600$ & 58.33 & 18.51 & 64.58 & 19.67 \\
\hline 15 & Kathi & $21.366669 / 78.257408$ & 27.08 & 3.93 & 35.42 & 5.32 \\
\hline 16 & Loni & $21.378971 / 78.180305$ & 47.92 & 10.88 & 35.42 & 12.73 \\
\hline 17 & Khadki & $21.440512 / 78.123169$ & 50.00 & 14.35 & 45.83 & 18.05 \\
\hline 18 & Hiwarkhed & $21.396545 / 78.068939$ & 18.75 & 3.01 & 22.92 & 3.00 \\
\hline 19 & Narayanpur & $21.036819 / 77.839081$ & 41.63 & 15.27 & 45.83 & 12.50 \\
\hline 20 & Dapori & $21.386913 / 78.058708$ & 50.00 & 17.82 & 47.92 & 17.59 \\
\hline 21 & Morshi & $21.351351 / 78.026848$ & 27.08 & 5.32 & 29.17 & 6.48 \\
\hline 22 & Khanapur & $21.313564 / 77.944221$ & 56.25 & 11.80 & 39.58 & 9.03 \\
\hline 23 & Khed & $21.286816 / 77.868927$ & 54.17 & 12.26 & 43.75 & 11.34 \\
\hline 24 & Kolevihir & $21.273340 / 77.842461$ & 27.08 & 6.71 & 29.17 & 4.62 \\
\hline 25 & Riddhapur & $21.243561 / 77.817818$ & 10.42 & 1.77 & 14.58 & 3.01 \\
\hline 26 & Dhamangaon & $21.222244 / 77.897881$ & 20.83 & 3.70 & 18.75 & 3.47 \\
\hline 27 & Lehgaon & $21.198622 / 77.952744$ & 35.42 & 4.86 & 31.25 & 6.71 \\
\hline 28 & Nerpinglai & $21.178944 / 78.025307$ & 22.92 & 4.39 & 37.50 & 6.71 \\
\hline 29 & Satargaon & $21.129595 / 78.073072$ & 29.17 & 6.94 & 27.08 & 5.78 \\
\hline 30 & Tivsa & $21.080996 / 78.059776$ & 27.08 & 7.17 & 22.92 & 6.71 \\
\hline 31 & Shendurjana Bazar A & $21.071243 / 78.036125$ & 31.25 & 3.93 & 22.92 & 5.32 \\
\hline 32 & Shendurjana Bazar B & $21.040308 / 78.054565$ & 43.75 & 11.34 & 54.17 & 9.49 \\
\hline
\end{tabular}




\begin{tabular}{|c|c|c|c|c|c|c|}
\hline 33 & Kawadgavhan & $21.005722 / 78.056297$ & 33.33 & 7.87 & 37.50 & 9.25 \\
\hline 34 & Kurha & $20.941765 / 78.057526$ & 39.58 & 9.49 & 22.92 & 6.94 \\
\hline 35 & Anjanwati & $20.905460 / 78.140945$ & 20.83 & 3.70 & 18.75 & 3.00 \\
\hline 36 & Dhakulgaon & $20.900702 / 78.129700$ & 43.75 & 14.12 & 39.58 & 12.26 \\
\hline 37 & Gunji & $20.859447 / 78.126190$ & 25.00 & 5.09 & 14.58 & 2.08 \\
\hline 38 & Dhamangaon & $20.755804 / 78.143257$ & 39.58 & 11.80 & 39.58 & 9.49 \\
\hline 39 & Jalka patache & $20.713381 / 78.152710$ & 16.67 & 2.31 & 33.33 & 4.62 \\
\hline 40 & Devgaon & $20.681091 / 78.138123$ & 31.25 & 10.88 & 43.75 & 9.26 \\
\hline 41 & Shendurjana & $20.725727 / 78.059837$ & 10.42 & 1.62 & 22.92 & 3.00 \\
\hline 42 & Jawara & $20.712641 / 78.026985$ & 47.92 & 11.34 & 43.75 & 14.12 \\
\hline 43 & Satephal & $20.754368 / 78.007439$ & 25.00 & 3.24 & 22.92 & 4.39 \\
\hline 44 & Kalamgaon & $20.764721 / 77.986305$ & 25.00 & 3.24 & 14.58 & 2.54 \\
\hline 45 & Songaon & $20.795628 / 77.981483$ & 54.17 & 18.05 & 45.83 & 15.28 \\
\hline 46 & Govt. Farm CR & $20.816608 / 77.980843$ & 50.00 & 11.11 & 45.83 & 10.18 \\
\hline 47 & Chirodi road & $20.827375 / 77.949455$ & 37.50 & 8.33 & 29.17 & 6.01 \\
\hline 48 & Chirodi & $20.871901 / 77.920975$ & 33.33 & 6.48 & 37.50 & 6.71 \\
\hline 49 & Wadgaon mahure & $20.964720 / 77.823738$ & 16.67 & 2.31 & 25.00 & 2.77 \\
\hline 50 & Shewati & $20.980495 / 77.857025$ & 41.67 & 8.33 & 35.42 & 6.71 \\
\hline 51 & Pimpalvihir & $21.028675 / 77.914795$ & 47.92 & 11.34 & 39.58 & 10.18 \\
\hline 52 & Mahuli jahangir A & $21.053570 / 77.881485$ & 17.59 & 4.86 & 31.25 & 3.47 \\
\hline 53 & Mahuli jahangir B & $21.054468 / 77.875603$ & 16.67 & 2.31 & 25.00 & 3.23 \\
\hline 54 & Wagholi & $21.088282 / 77.889664$ & 43.75 & 11.10 & 52.08 & 11.80 \\
\hline 55 & Dawargaon & $21.104092 / 77.881348$ & 45.83 & 7.40 & 37.50 & 5.32 \\
\hline 56 & Narsingpur & $21.107113 / 77.825760$ & 39.58 & 14.58 & 39.58 & 11.34 \\
\hline 57 & Dewari & $21.094004 / 77.812752$ & 22.92 & 4.39 & 25.00 & 5.09 \\
\hline 58 & Dabha & $20.826481 / 77.733650$ & 18.75 & 2.08 & 27.08 & 3.47 \\
\hline 59 & Jalu & $20.789574 / 77.744354$ & 43.75 & 6.25 & 33.33 & 5.55 \\
\hline 60 & Javara & $20.779692 / 77.748238$ & 43.75 & 9.95 & 35.42 & 10.41 \\
\hline 61 & Dhanora & $20.701618 / 77.744415$ & 20.83 & 3.24 & 35.42 & 4.39 \\
\hline 62 & Siddhnathpur & $20.698893 / 77.725929$ & 43.75 & 11.34 & 43.75 & 8.56 \\
\hline 63 & Dhanera fasi & $20.720860 / 77.686241$ & 12.50 & 1.85 & 25.00 & 4.39 \\
\hline 64 & Ghawalsari & $20.768379 / 77.699270$ & 35.42 & 5.32 & 25.00 & 4.62 \\
\hline 65 & Loni takali & $20.783119 / 77.668846$ & 33.33 & 5.09 & 25.00 & 5.09 \\
\hline 66 & Murha & $21.105963 / 77.302162$ & 37.50 & 11.11 & 37.50 & 8.79 \\
\hline 67 & Takarkheda & $21.155949 / 77.314034$ & 35.42 & 6.71 & 35.42 & 6.71 \\
\hline 68 & Dhanegaon & $21.148237 / 77.358475$ & 25.00 & 3.70 & 22.92 & 2.54 \\
\hline 69 & Anjangaon & $21.169685 / 77.293846$ & 25.00 & 3.70 & 22.92 & 3.47 \\
\hline 70 & Sategaon & $21.161844 / 77.221146$ & 35.42 & 7.17 & 37.50 & 8.79 \\
\hline 71 & Takala & $21.149736 / 77.423096$ & 31.25 & 5.78 & 25.00 & 6.48 \\
\hline 72 & Isegaon & $21.180529 / 77.559967$ & 33.33 & 5.09 & 29.17 & 5.55 \\
\hline 73 & Khanapur B & $21.222572 / 77.496910$ & 39.58 & 8.10 & 29.17 & 4.16 \\
\hline 74 & Paratwada & $21.295736 / 77.528702$ & 52.08 & 10.41 & 25.00 & 5.55 \\
\hline 75 & Dhamangaon & $21.295909 / 77.481285$ & 37.50 & 6.48 & 35.42 & 7.17 \\
\hline 76 & Parasapur & $21.255491 / 77.412094$ & 22.92 & 4.39 & 37.50 & 6.01 \\
\hline 77 & Pathrot & $21.205725 / 77.355133$ & 39.58 & 9.02 & 25.00 & 4.63 \\
\hline 78 & Tondgaon & $21.248672 / 77.564194$ & 41.67 & 13.42 & 43.75 & 11.34 \\
\hline 79 & Pimpri & $21.240486 / 77.644196$ & 37.50 & 6.48 & 37.50 & 6.94 \\
\hline 80 & Haidatpur & $21.232422 / 77.706490$ & 33.33 & 4.62 & 27.08 & 4.86 \\
\hline 81 & Kondwardha & $21.252337 / 77.628304$ & 22.92 & 3.00 & 27.08 & 4.39 \\
\hline 82 & Kurha & $21.297943 / 77.632507$ & 41.67 & 12.96 & 31.25 & 5.32 \\
\hline 83 & Kharpi & $21.330448 / 77.583687$ & 31.25 & 4.86 & 37.50 & 6.48 \\
\hline
\end{tabular}

Maximum root rot incidence was recorded in orchards of Jarud, Pimpleshevda, Udapur, and Khanapur during 2016 $(54.16 \%)$, whereas minimum root rot incidence was recorded in orchards of Zatamziri (A), Riddhapur, Shendurjana and Dhanera fasi villages $(8.33 \%)$. Maximum root rot intensity of $18.72 \%$ was recorded in Jarud and least disease intensity $(0.92 \%)$ was observed at Riddhapur, Shendurjana and Dhanera fasi. In 2017, maximum disease incidence $(70.83 \%)$ and intensity (28.24\%) of root rot was recorded in orchard of village Jarud. Minimum incidence of root rot (12.50\%) was recorded in orchards of Tivsa ghat, Riddhapur, Shendurjana villages, whereas, minimum disease intensity was recorded in Riddhapur (2.30\%).

Maximum gummosis incidence $(62.50 \%)$ was observed in orchards of village Udapur and the minimum disease incidence (12.50\%) was observed in village Gunji, Kalamgaon and Dhanegaon. The gummosis intensity was found maximum in Udapur and Dapori i.e. 18.05\% however, minimum disease intensity $(1.38 \%$ ) was observed in Gunji and Dhanegaon in 2016. In case study of gummosis during the year 2017, minimum disease incidence of $12.50 \%$ was observed in village Riddhapur but minimum disease intensity of $2.77 \%$ was recorded in orchards of location Zatamziri (A), Hiwarkhed, Dhamangaon, Anjanwati, Gunji and Kalamgaon. In both the years study, similar trend was observed hence here pooled data of that two years (2016 and 2017) study is presented. According to rapid roving survey of root rot in selected orchards, pooled data indicate similar disease progress with root rot incidence in the range of 10.42 to $62.50 \%$ and intensity from 1.62 up to $23.48 \%$. In case of gummosis pooled data indicate similar trend of disease development with gummosis incidence in the range of 14.58 to $64.58 \%$ and intensity in between 2.08 to $19.91 \%$ (Table 1 ). The mandarin orchards surveyed in Amravati district were severely affected with Phytophthora diseases. Heavy rainfall during July up to November was the peak season to establish 
the disease in orchards, high humidity and optimum temperature range $18^{\circ} \mathrm{C}-35^{\circ} \mathrm{C}$ was found to conducive for the disease growth. Wagh et al. (2018) ${ }^{[13]}$ recorded incidence and intensity of root rot in the range of 18 to $40 \%$ and intensity 6.70 to $24.55 \%$. In their study gummosis incidence was found in the range of 14 to $50.50 \%$ and intensity in the range of 8.50 to $28 \%$ in Nagpur mandarin in Warud and Morshi tahasils of Central India. Survey for damping off of seedling, root rot, collar rot, foot rot, brown rot and gummosis of citrus were undertaken in citrus growing belts of India by Naqvi (2006) ${ }^{[11]}$ and observed 10 to $100 \%$ citrus decline with 5 to 12 propagules/cc soil in Amravati district in Central India. Naqvi (1999) ${ }^{[10]}$ reported 20 to $100 \%$ plants of citrus affected with decline in Amravati district. The results of the present findings are in accordance to Jagtap et al. (2012) ${ }^{[5]}$ who carried out roving survey of 103 sweet orange orchards to assess the disease incidence and severity of citrus gummosis and noticed disease incidence in the range of 10 $63.38 \%$ in Marathwada region. The result shows the seriousness of the issue need to be tackled to take corrective measures in time.

\section{Acknowledgments}

The authors are thankful to the Information Technology Research Academy (ITRA), Ministry of Information Technology, GOI, New Delhi for providing fellowship and funding to conduct this research work.

\section{References}

1. Das AK, Kumar A, Ingle A, Nerkar S. Molecular identification of Phytophthora spp. causing citrus decline in Vidarbha region of Maharashtra. Indian Phytopath. 2011; 64(4):342-345.

2. Gade RM, Koche MD. Integrated disease management for root rot and gummosis in Nagpur mandarin. Indian Phytopath. 2012; 65(3):272-275.

3. Gade RM. Biological and chemical management of Phytophthora root rot / collar rot in citrus nursery. The bioscan. 2012; 7(4):631-635.

4. Gade RM, Bambawale OM, Sangle UR, Shinde VB. Chemical management of gummosis in Nagpur mandarin (Citrus reticulata Blanco). Pesticides Res. J. 2006; 18(2):169-172.

5. Jagtap GP, Dhavale MC, Dey U. Symptomatology, survey and surveillance of citrus gummosis caused by Phytophthora spp. Scientific Journal of Agricultural. 2012; 1(1):14-20.

6. Lakshmi T, Gopi V, Sankar T, Sarada G, Lakshmi L, Ramana KTV et al., Status of diseases in sweet orange and acid lime orchards in Andhra Pradesh, India. Int. J. Curr. Microbiol. App. Sci. 2014; 3(5):513-518.

7. Meena NL, Shah R. Efficacy of fungicides and phyto extracts against Phomopsis citri causing fruit rot in Nagpur mandarin orange var. Nagpur Santra (Citrus reticulata). J. Mycol. Pl. Pathol. 2005; 35(2):231-216.

8. Naqvi SAMH. Prevalence of Phytophthora spp. pathogenic to citrus in orange groves of Vidarbha, Maharashtra. Indian J. Mycol. Pl. Pathol. 1988; 18(3):274-276.

9. Naqvi SAMH. Efficacy of some fungicides in control of Phytophothora diseases of Nagpur mandarin in central India. Indian Phytopath. 1993; 46:430-434.

10. Naqvi SAMH. Distribution of Phytophthora spp. and mating types pathogenic to citrus in Vidarbha and Marathwada region of Maharashtra and North Eastern states of India. In Citrus Proceeding, International Symposium on Citriculture, 1999, 1073-1080.

11. Naqvi SAMH. Distribution of citrus Phytophthora spp. and mating types pathogenic to citrus in central india. J. Mycol. Pl. Pathol. 2006; 36(1):44-49.

12. Tsao PH. Why many Phytophthora root rots and crown rots of tree and horticultural crops remain undetected. Bul. OEPP/EPPO Bul. 1990; 20:11-17.

13. Wagh SP, Gade RM, Lad RS. Survey on Phytophthora diseases in Nagpur mandarin. Journal of Plant Disease Sciences. 2018; 13(1):32-35. 